\title{
Trace element geochemistry of Bitlis ignimbrites sourced by Quaternary Nemrut Volcano: inferences for A2-type magma generation in Eastern Anatolia post-collisional extensional setting
}

\author{
Hakan ÇOBAN a,* (D), Özcan Ali KALKAN b (D) \\ a Bitlis Eren University, Department of Civil Engineering, TR-13000, Bitlis, Turkey \\ b Batman University, Department of Geological Engineering, TR-72100, Batman, Turkey
}

\section{ART ICLE IN F O}

Article history:

Received 10 November 2021

Received in revised form 22 November 2021

Accepted 01 December 2021

\section{Keywords:}

Bitlis ignimbrite

A2-type magma

K-Ar dating

Eastern Anatolia

\begin{abstract}
A B S T R A C T
In the study presented here, we investigated the whole-rock K-Ar dating and petrological significance of trace element compositions Bitlis (Eastern Anatolia) ignimbrites associated with explosive activities of the well-known Quaternary Nemrut volcano. Considering the previous age determinations (40.9 ka $264.1 \mathrm{ka}$ ) of ignimbrites sourced in Nemrut volcano, and because they contain lithic clasts, obtained whole-rock K-Ar age of Bitlis ignimbrite flow deposits suggest that they are younger than late Pleistocene $(<790 \mathrm{ka})$, and occurred as the first products of pre-caldera stages of Nemrut stratovolcano. Bitlis trachydacitic ignimbrites with shoshonitic affinity are characterized by the typical negative anomalies of $\mathrm{Eu}, \mathrm{Nb}-\mathrm{Ta}$, and $\mathrm{Ti}$ in chondrite-normalized spider and multi-element variation diagrams, and plot in the fields of within-plate and post-collisional tectonic setting in $\mathrm{Rb} v \mathrm{vs}+\mathrm{Nb}$ discrimination diagram. Accordingly, similar to that of Nemrut volcanic products, trace element signatures (e.g., high $\mathrm{Nb}, \mathrm{Ce}, \mathrm{Y}$, and $\mathrm{Zr}$ contents) of Bitlis ignimbrites show coincidence with geochemical characteristics of $\mathrm{A}_{2}$-type silicic magmas. Relative to the upper crust, higher $\mathrm{La} / \mathrm{Ba}$ and $\mathrm{Nb} / \mathrm{La}$, and lower $\mathrm{Ba} / \mathrm{Ta}$ and $\mathrm{La} / \mathrm{Ta}$ ratios of $\mathrm{Bitlis}$ ignimbrites, which are close to that of Nemrut basalts previously reported as the most recent volcanic products, suggest an interaction between OIB-like basaltic magma and upper crust. Our results point to $\mathrm{A}_{2}$-type silicic magma generation in Eastern Anatolia post-collisional extensional setting, and Nemrut lava and pyroclastic rocks (e.g., Bitlis ignimbrites) formed by partial melting of upper crustal rocks at shallow level via interaction with OIB-like basaltic magma derived from a common mantle source.
\end{abstract}

\section{Introduction}

Felsic ignimbrite flows generated by explosive Quaternary active Nemrut volcano from Eastern Anatolia (e.g., Karaoğlu et al., 2005; Özdemir et al., 2006; Koralay et al., 2011, 2014; Çubukcu et al., 2012, Sumita and Schminke et al., 2013; Schminke and Sumita, 2014) are well exposed along with Bitlis valley. Although, stratigraphic position, mineralogical, petrographical, and major-chemical compositions of Bitlis ignimbrites have been studied by some researchers (e.g., Karaoğlu et al., 2005; Koralay et al., 2011, 2014), geochronological dating and trace element compositions of these rocks are still lacking. Hence, in this study, $\mathrm{K}-\mathrm{Ar}$ age determination and trace and rare earth element (REE) analysis have been performed on bulk-rock samples of Bitlis ignimbrites. The magma type, from which they produced, geochemical characteristics and petrological signatures of Bitlis ignimbrites and associated felsic-silicic volcanic rocks of Nemrut volcano, which are derived from a common magma source, have also been discussed.

\subsection{Bitlis ignimbrites in the geological setting}

Quaternary active Nemrut volcano is situated $12 \mathrm{~km}$ north of the Bitlis-Zagros suture zone, southern margin of continental collision between Arabian and Anatolian plates (Çubukçu et al., 2012) (Figure 1). The Bitlis ignimbrites exposed in the Bitlis area (Eastern Anatolia) are a restricted-volume, pyroclastic deposit generated by Nemrut volcano in the Quaternary (Fig.

\footnotetext{
* Corresponding author. Tel.: +0 5327306733

E-mail address: hcoban@beu.edu.tr

ORCID : 0000-0002-9614-6818 (H. Coban), 0000-0002-1743-4425 (O.A. Kalkan)
} 
1, Özdemir et al., 2003; Karaoğlu et al., 2005; Koralay et al., 2011, 2014). The Bitlis ignimbrite flows overly the metamorphic basements (known as Bitlis metamorphics) comprising Devonian to Cretaceous metasedimentary rocks along with Bitlis valley (Fig. 1). Recent alluvium and travertines are the youngest lithological units in the study area (Fig. 1). The columnar structures of Bitlis ignimbrites along with Bitlis valley are their most characteristic feature (Fig. 2). They have a massive, matrix-supported structure, poorly sorted, with lithic and pumice clasts of varying size scattered in the ash matrix, not showing evident grading of coarse clasts (Koralay et al., 2011). They are generally homogeneous throughout their thickness. The Bitlis silicic ignimbrites associated with Quaternary Nemrut explosive stratovolcano have a high thickness (up to $8 \mathrm{~m}$ ) in Bitlis valley. Detailed mineralogical and petrographical properties of these ignimbrites are not given here and can be found in Koralay et al., (2011 and 2014).

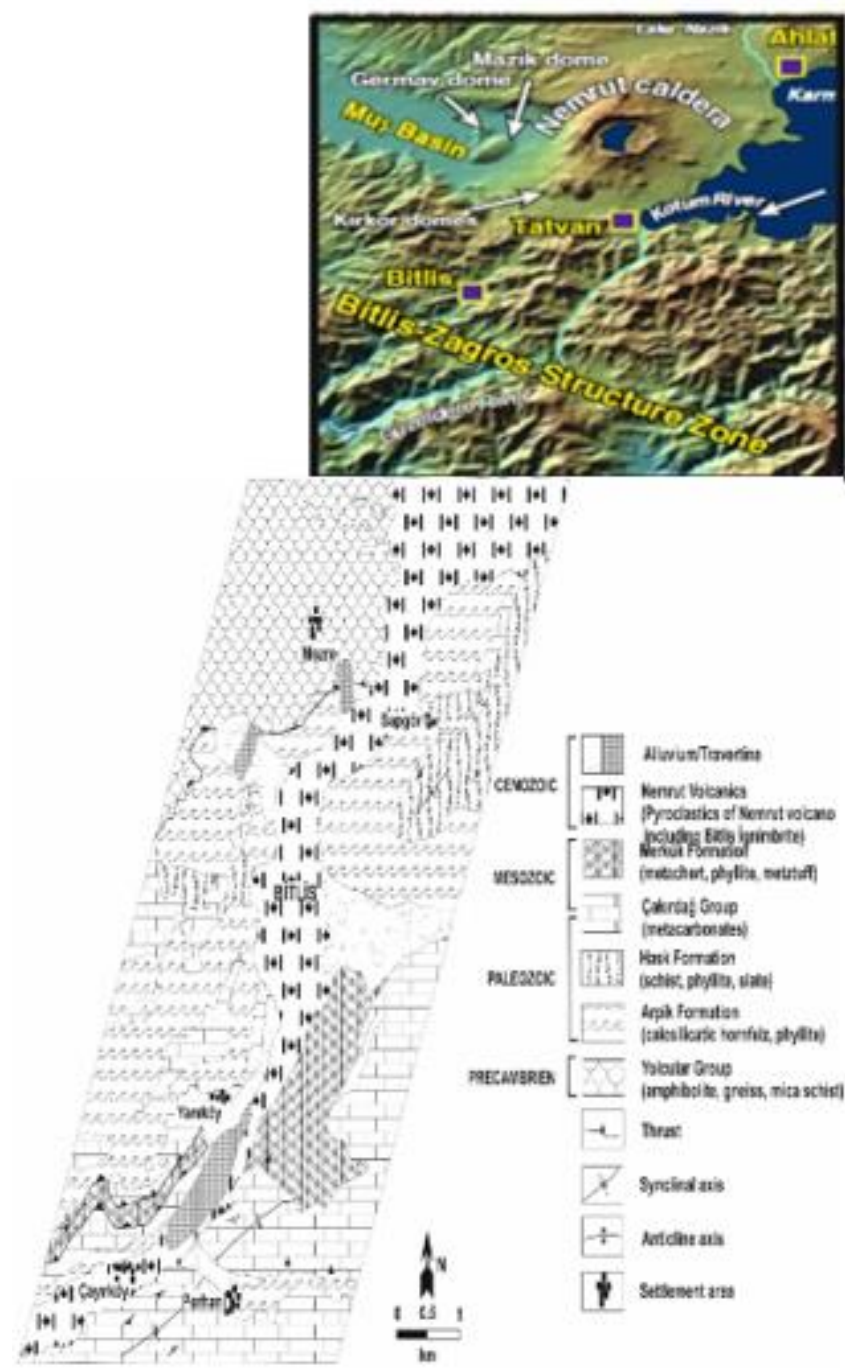

Figure 1. Location (upper figure) and geological (lower figure) maps of the study area (modified from Sumita and Schminke et al., 2013, and Şengün et al., 1991).

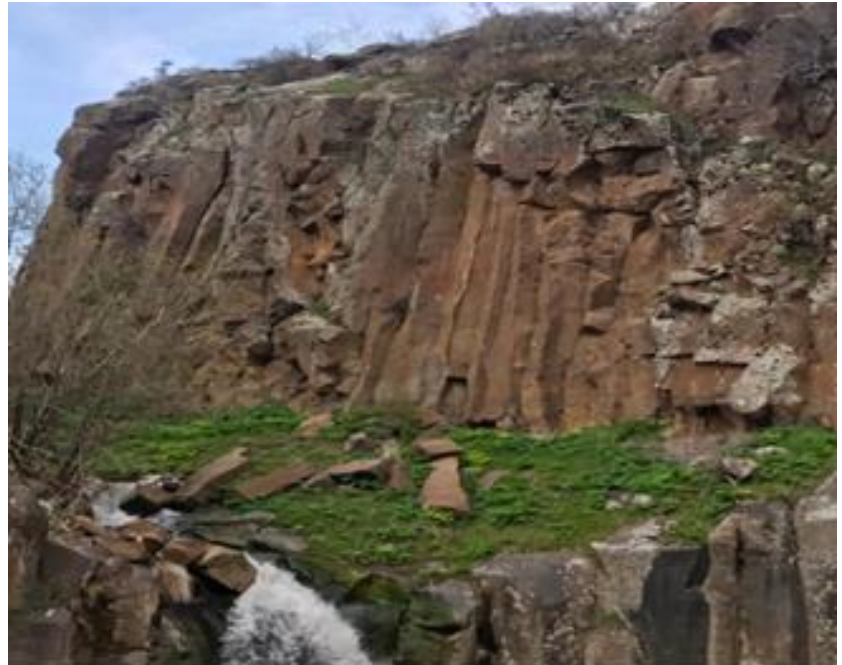

Figure 2. Field view of Bitlis ignimbrites showing the columnar structure, in Bitlis valley.

\section{Methodology}

Whole-rock K-Ar isotopic age analyses of the sample BH4 from Bitlis ignimbrites were conducted in the ACT-LAB (Canada), using the MI-1201 IG mass spectrometer. Aliquots of the sample were weighted into Al container, loaded into the sample system of the extraction unit, degassed at $\sim 100^{\circ} \mathrm{C}$ during 2 days to remove the surface gases. Argon is extracted from the sample in a double vacuum furnace at $1700^{\circ} \mathrm{C}$. The determination of radiogenic argon content was carried out twice on MI-1201 IG mass-spectrometer by isotope dilution method with ${ }^{38} \mathrm{Ar}$ as the spike, which is introduced to the sample system prior to each extraction. The extracted gases were cleaned up in a two-step purification system. Then pure Ar is introduced into a custom-built magnetic sector mass spectrometer (Reinolds type). Two globally accepted standards (P-207 Muscovite and 1/65 "Asia" rhyolite matrix) were measured for ${ }^{38} \mathrm{Ar}$ spike calibration. For age calculations the international values of constants were used as follow:

\section{$\lambda \mathrm{K}=0.581 * 10-10 \mathrm{y}-1, \quad \lambda \beta-=4.962 * 10-10 \mathrm{y}-1, \quad 40 \mathrm{~K}=0.01167$ (at.\%).}

The major, trace and REE analyses of five bulk-rock samples of Bitlis ignimbrites have been performed in the Geochemistry Research Laboratories of Istanbul Technical University (ITU/JAL). The samples were grounded using a Tungsten Carbide milling device. Major elements of the samples were analyzed using a BRUKER S8 TIGER model X-ray fluorescence spectrometer with a wavelength range from 0.01-12 nm. Trace elements were analyzed by Inductively Coupled Plasma-Mass Spectrometry using an ELAN DRC-e Perkin Elmer model. Approximately $50 \mathrm{mg}$ of powdered sample was digested in two steps. The first step was completed with $6 \mathrm{ml}$ of $37 \% \mathrm{HCl}, 2 \mathrm{ml}$ of $65 \% \mathrm{HNO}_{3}$, and $1 \mathrm{ml}$ of $38-40 \%$ $\mathrm{HF}$ in a pressure- and temperature-controlled Teflon beaker using a Berghoff Microwave at $135^{\circ} \mathrm{C}$. The second step was completed with the addition of $6 \mathrm{ml}$ of $5 \%$ boric acid solution. 


\section{Results and Discussion}

\section{1. $K$-Ar dating}

Obtained data from the whole-rock K-Ar geochronological dating of Bitlis ignimbrites gave the age of 790 ka (late Pleistocene) and presented in Table 1 . The historically active Nemrut Volcano (Eastern Anatolia) has been the source of intense Plinian eruptions for $>530.000$ years (Sumita and Schmincke, 2013). Previous age determinations of ignimbrites sourced in Nemrut volcano gave the ages of between $40.9 \mathrm{ka}$ and 264.1 ka (Sumita and Schmincke, 2013). Çubukcu et al., (2012) indicated that the oldest volcanic rocks ( $\sim 1.0 \mathrm{Ma})$ from Nemrut caldera are determined from metaluminous trachytes/rhyolites. Apart from the older age of $2.5 \mathrm{Ma}$ for a widespread basaltic lava flow exposed along the Bitlis Gorge, all other dates range from ca. 0.5 Ma to the Holocene (Sumita and Schmincke, 2013). Considering the overall eruptive history of Quaternary Nemrut stratovolcano (e.g., Özdemir et al., 2006; Çubukçu et al., 2012; Sumita and Schminke et al., 2013; Schminke and Sumita, 2014), obtained age data of the Bitlis ignimbrites including lithic clasts indicate that they are younger than late Pleistocene (<790.000 years), and corresponds to the first silicic products of the pre-caldera stage of Nemrut volcano, which confirm the initiation of early-stage silicic pyroclastic products with trachydacitic ignimbritic flow deposits at the south of caldera.

Table 1. K-Ar isotopic age analyses of Bitlis ignimbrites

\begin{tabular}{|c|l|l|l|l|l|}
\hline Sample & $\mathrm{K}, \% \pm \sigma$ & $\begin{array}{l}{ }^{40} \mathrm{Ar} \text { rad, } \\
\text { (ng/g) }\end{array}$ & $\begin{array}{l}\%{ }^{40} \mathrm{Ar} \\
\text { air }\end{array}$ & $\begin{array}{l}\text { Age, } \\
\text { Ma }\end{array}$ & $\begin{array}{l}\text { Ma } \\
\text { Error 2 } \sigma\end{array}$ \\
\hline & & & & & \\
BH-4 & $4.27 \pm 0.05$ & $0.235 \pm 0.006$ & 78.7 & 0.79 & 0.04 \\
\hline
\end{tabular}

\subsection{Trace element inferences for magma style of Bitlis ignimbrites and Nemrut felsic volcanic rocks}

Major oxide, trace, and REE analyses of five samples from Bitlis ignimbrites are presented in Table 2. In terms of the TAS (total alkali-silica) diagram of Le Maitre et al., (2002), Bitlis ignimbrites can be classified as trachydacite in composition (not shown). Bitlis trachydacitic ignimbrites $\left(\mathrm{K}_{2} \mathrm{O} / \mathrm{Na}_{2} \mathrm{O}\right.$ ratios range between 1.1 to 1.5) and Nemrut felsic-silicic volcanic rocks with potassic character (e.g., Özdemir et al., 2006; Çubukçu et al., 2012) show a shoshonitic affinity $\left(\mathrm{K}_{2} \mathrm{O} / \mathrm{Na}_{2} \mathrm{O}=\right.$ $\approx 1$ ) (not shown). As shown in Figs. 3a and b, Bitlis ignimbrites demonstrate pronounced $\mathrm{Nb}-\mathrm{Ta}, \mathrm{P}$, and $\mathrm{Ti}$ depletions in the primitive-mantle normalized multi-element diagram, and an obvious negative $\mathrm{Eu}$ anomaly in chondrite-normalized REEdiagram, which are consistent with that of the upper crust (Rudnick and Gao, 2004). Such geochemical anomalies are also akin to Nemrut felsic-silicic volcanic rocks having slightly but remarkable negative anomalies of $\mathrm{Nb}-\mathrm{Ta}, \mathrm{P}$, and $\mathrm{Ti}$ (Özdemir et al., 2006; Çubukçu et al., 2012). Slight negative Nb-Ta depletion is also observed in Nemrut basalts (Özdemir et al., 2006). Considering their geochemical characteristics, the Bitlis ignimbrites and Nemrut felsic-silicic volcanic rocks demonstrate a chemical affinity to A-type silicic magmas with high FeOtot/(FeOtot+MgO) and $\mathrm{Ga} / \mathrm{Al}$ ratios, $\sum\left(\mathrm{K}_{2} \mathrm{O}+\mathrm{Na}_{2} \mathrm{O}\right)$, and $\sum(\mathrm{Zr}+\mathrm{Nb}+\mathrm{Ce}+\mathrm{Y})$ contents (Whalen et al., 1987; Eby, 2011), and the Bitlis ignimbrites and Nemrut felsic-silicic volcanic rocks fall well within the fields of A-type silicic magmas (Figs. $4 \mathrm{a}$ and b). For A-type magmas, Eby (1992) further divided them into genetically distinct A1-anorogenic and A2-postorogenic chemical subgroups. As shown in Fig 4c, the Bitlis ignimbrites and Nemrut felsic volcanic rocks plot within the A2 subgroup, which are also compatible with within-plate and post-collisional settings, which are shown in Fig. 4d.
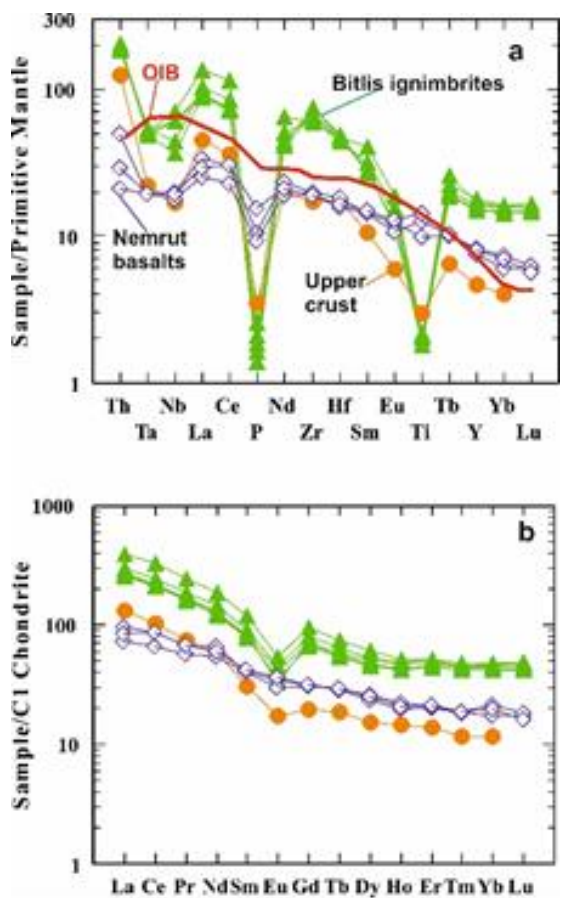

Figure 3. Primitive mantle-normalized multielement (a) and chondrite-normalized REE (b) diagrams of the Bitlis ignimbrites. Normalized values and OIB are from Sun and McDonough (1989). The upper crust is from Rudnick and Gao (2004). Nemrut basalts are from Özdemir et al., (2006).
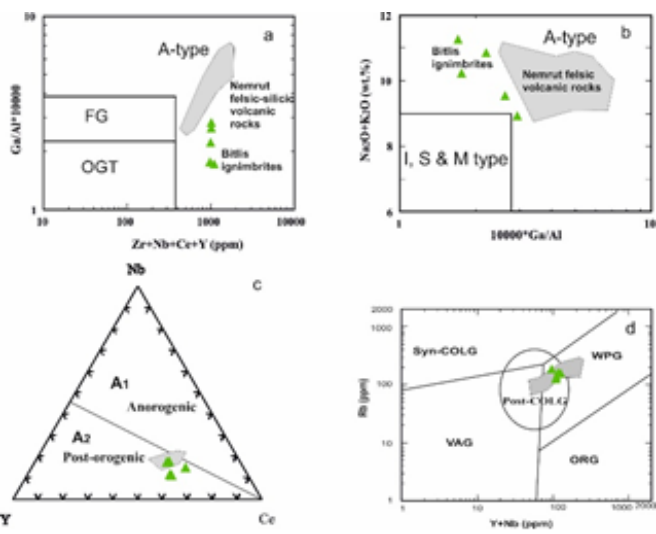

Figure 4. $\mathrm{Ga} / \mathrm{Al}$ vs $\mathrm{Zr}+\mathrm{Nb}+\mathrm{Ce}+\mathrm{Y}$ (a), $\mathrm{Na} 2 \mathrm{o}+\mathrm{K} 2 \mathrm{O}$ vs $\mathrm{Ga} / \mathrm{Al}$ (b), $\mathrm{Y}-\mathrm{Nb}-\mathrm{Ce}$ triangle (c) and $\mathrm{Rb}$ vs $\mathrm{Y}+\mathrm{Nb}$ (d) variation diagrams for Bitlis ignimbrites. For comparison, Nemrut felsic-silicic volcanic rocks (Özdemir et al., 2006) are also plotted. A-type, A1 and A2 type, FG, OGT, I, S, and M type magma fields are from Whalen et al., (1987) and Eby, (2011). Syn-COLG, ORG, VAG, WPG, and Post-COLG fields in d are from Pearce (1996). 
Table 2. Major, trace and REE analysis of Bitlis ignimbrites.

\begin{tabular}{|l|r|r|r|r|r|r|}
\hline (wt.\%) & \multicolumn{1}{|c|}{ BH1 } & BH2 & BH3 & BH4 & \multicolumn{1}{|c|}{ BH5 } \\
\hline SiO2 & 67,14 & $66,99 \%$ & $65,06 \%$ & $64,64 \%$ & $67,08 \%$ \\
Ti02 & $0,46 \%$ & $0,46 \%$ & $0,46 \%$ & $0,44 \%$ & $0,39 \%$ \\
Al203 & $14,12 \%$ & $13,96 \%$ & $15,47 \%$ & $15,39 \%$ & $13,71 \%$ \\
Fe203 & $3,95 \%$ & $3,97 \%$ & $3,49 \%$ & $4,43 \%$ & $4,46 \%$ \\
Mg0 & $0,13 \%$ & $0,21 \%$ & $0,12 \%$ & $0,16 \%$ & $0,17 \%$ \\
CaO & $1,32 \%$ & $1,36 \%$ & $1,25 \%$ & $1,27 \%$ & $1,16 \%$ \\
Na20 & $3,54 \%$ & $4,54 \%$ & $5,31 \%$ & $4,90 \%$ & $4,14 \%$ \\
K20 & $5,33 \%$ & $5,65 \%$ & $5,91 \%$ & $5,91 \%$ & $5,36 \%$ \\
Mn0 & $0,05 \%$ & $0,11 \%$ & $0,08 \%$ & $0,10 \%$ & $0,08 \%$ \\
P205 & $0,11 \%$ & $0,08 \%$ & $0,07 \%$ & $0,09 \%$ & $0,06 \%$ \\
L0I & $3,48 \%$ & $2,26 \%$ & $2,34 \%$ & $2,25 \%$ & $3,02 \%$ \\
Total & $99,63 \%$ & $99,59 \%$ & $99,56 \%$ & $99,58 \%$ & $99,63 \%$ \\
\hline
\end{tabular}

\begin{tabular}{|c|c|c|c|c|c|}
\hline \multicolumn{6}{|c|}{ (trace element in ppm) } \\
\hline Sc & 7 & 6 & 4 & 4 & 4 \\
\hline Co & 39 & 21 & 36 & 15 & 12 \\
\hline $\mathbf{N i}$ & 59 & 83 & 33 & 25 & 130 \\
\hline Ga & 21 & 13 & 142 & 18 & 19 \\
\hline $\mathbf{R b}$ & 157 & 138 & 186 & 127 & 165 \\
\hline $\mathbf{S r}$ & 104 & 52 & 84 & 57 & 50 \\
\hline $\mathbf{Z r}$ & 665 & 681 & 835 & 724 & 748 \\
\hline Nb & 50 & 31 & 26 & 43 & 43 \\
\hline Ba & 749 & 763 & 772 & 657 & 566 \\
\hline $\mathbf{P b}$ & 66 & 105 & 41 & 45 & 43 \\
\hline $\mathbf{U}$ & 9 & 8 & 8 & 7 & 6 \\
\hline $\mathbf{Y}$ & 76,000 & 81,000 & 69,000 & 67,000 & 73,000 \\
\hline Hf & 14,000 & 13,600 & 15,000 & 14,400 & 19,000 \\
\hline Ta & 2,100 & 2,000 & 1,900 & 2,100 & 2,000 \\
\hline
\end{tabular}

\begin{tabular}{|l|r|r|r|r|r|r|r|}
\hline \multicolumn{2}{|l|}{ (REE in ppm) } \\
\hline La & 92,987 & & 70,603 & 61,865 & 60,710 & 64,771 \\
Ce & 202,761 & 149,41 & 131,69 & 128,13 & 130,28 \\
7 & 7 & 5 & 8 \\
Pr & 23,343 & 17,592 & 15,461 & 15,119 & 16,123 \\
Nd & 87,620 & 68,152 & 57,639 & 56,159 & 60,480 \\
Sm & 18,131 & 14,025 & 12,360 & 11,858 & 12,449 \\
Eu & 3,154 & 2,596 & 2,425 & 2,054 & 1,906 \\
Gd & 19,604 & 16,281 & 14,113 & 13,342 & 14,565 \\
Tb & 2,788 & 2,405 & 2,057 & 2,007 & 2,176 \\
Dy & 15,328 & 13,502 & 11,791 & 11,640 & 12,813
\end{tabular}

\begin{tabular}{|c|c|c|c|c|c|}
\hline Ho & 2,934 & 2,789 & 2,449 & 2,403 & 2,688 \\
\hline Er & 8,461 & 8,478 & 7,663 & 7,348 & 8,121 \\
\hline Tm & 1,140 & 1,210 & 1,121 & 1,064 & 1,166 \\
\hline $\mathbf{Y b}$ & 7,782 & 8,026 & 7,325 & 7,076 & 7,874 \\
\hline Lu & 1,147 & 1,228 & 1,106 & 1,066 & 1,220 \\
\hline Th & 15,736 & 16,637 & 16,494 & 16,104 & 17,127 \\
\hline
\end{tabular}

\subsection{Petrological inferences}

Based on the trace element variations, it can be concluded that the Nemrut stratovolcano and derivative felsic volcanic and pyroclastic products (e.g., Bitlis ignimbrites) were derived from an A2-type silicic magma, which occurs in post-collisional or post-tectonic setting (Eby, 2011). In tectonic discrimination diagrams, overlapping post-orogenic and within-plate settings of A2-type Quaternary Nemrut felsic-silicic volcanic and pyroclastic products are consistent with the magma emplacement in a post-collisional extensional tectonic environment in Eastern Anatolia. Although Nemrut volcanic and pyroclastic products (e.g., Bitlis ignimbrites) show close affinity to the upper crust (see Figs. 3a-b), their A2-type magma character also requires the role of mantle-derived basaltic magma on their genesis (Medlin et al., 2015). The interaction of mantle-derived magma with crust can also be inferred from exposed basaltic magma eruptions of Nemrut caldera (e.g., Özdemir et al., 2006; Çubukçu et al., 2012). To confirm the interaction between mantle-derived magma and upper crust in the genesis of Nemrut volcanic and associated pyroclastic rocks (e.g., Bitlis ignimbrites), we used the $\mathrm{La} / \mathrm{Ba}$ versus $\mathrm{La} / \mathrm{Nb}$ (Saunders et al., 1992), and Ba/Ta versus La/Ta (Kay and Copeland, 2006) variation diagrams and shown in Figs. 5a-b. In these diagrams, there is a close affinity between Bitlis ignimbrites and Nemrut basalts, and they show a geochemical tendency between OIB and the upper crust, suggesting an interaction between them. Based on all these results, we conclude that Nemrut felsic-silicic volcanic and pyroclastic rocks derived from partial melting of an upper crustal source interacting with OIB-like (possibly asthenospheric) mantlederived magma. Emplacement of asthenospheric magma in the shallow upper crustal level along with extensional faults in post-collisional tectonic setting caused the partial melting and assimilation of the upper crust. OIB-like basaltic magma possibly contributed to the silicic A2-type magma batch, and explosive activity of Nemrut volcano produced felsic-silicic volcanic and pyroclastic (e.g., Bitlis ignimbrites) products during the Quaternary period. 

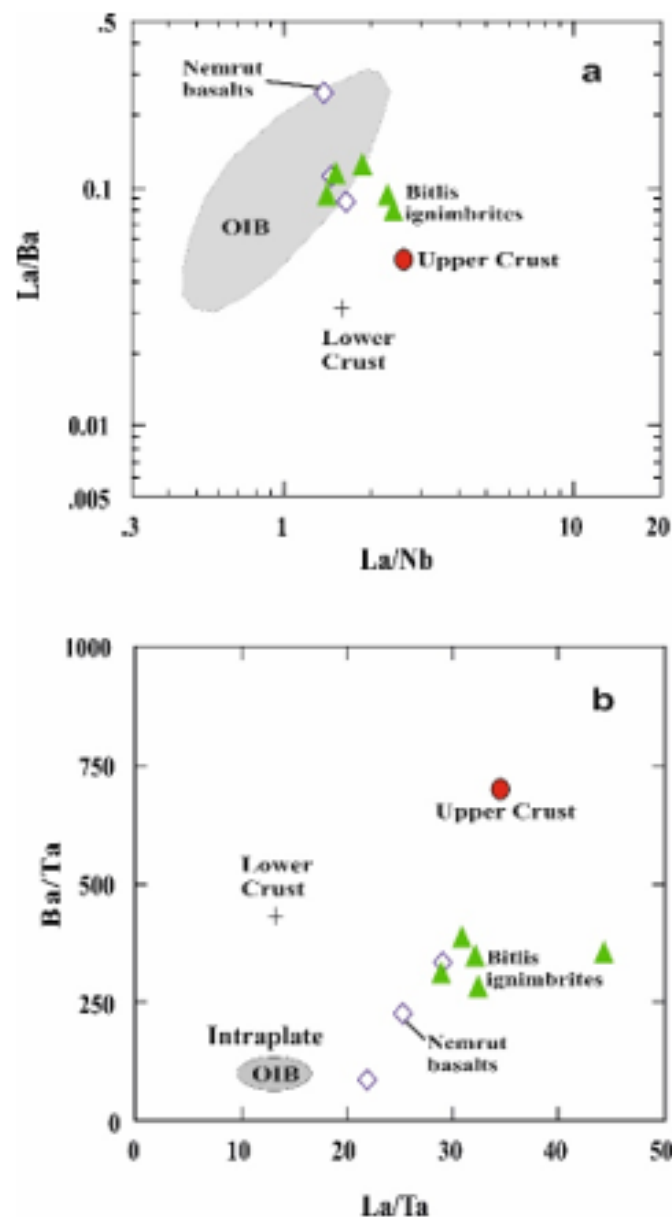

Figure 5. $\mathrm{La} / \mathrm{Ba}$ vs $\mathrm{La} / \mathrm{Nb}$ (a) and $\mathrm{Ba} / \mathrm{Ta}$ vs $\mathrm{La} / \mathrm{Ta}$ (b) variation diagrams of Bitlis ignimbrites. For comparison, Nemrut basalts (Özdemir et al., 2006) are also plotted. The upper and lower crust are from Rudnick and Gao (2004). The field intraplate is adapted from Kay and Copeland (2002). OIB field in 'a' is from Saunders et al., (1992).

\section{Conclusions}

Eruptions of Bitlis trachydacitic ignimbrites, produced by the Quaternary Nemrut stratovolcano during the pre-caldera stage in Eastern Anatolia post-collisional setting are younger than $790 \mathrm{ka}$, and similar to felsic-silicic volcanic rocks of Nemrut volcano, exhibit the chemical characteristics of A2-type silicic magmas. Trace element variations also suggest that the magma producing the Nemrut volcano was originated by partial melting of upper crustal rocks via emplacement of the mantlederived OIB-like magma at the shallow crustal level under extensional tectonic. OIB-like basaltic magma was also contributed to the composition of the magma chamber during its interaction with the upper crust. Trace element variations and magma style of Nemrut volcanic and pyroclastic (e.g., Bitlis ignimbrites) rocks confirm the A2-type silicic magma generation in Eastern Anatolia post-collisional extensional setting during Quaternary.

\section{Acknowledgments}

We would like to thank Dr. Mustafa KUMRAL (ITU), who conducted geochemical analyses of rock samples at Istanbul Technical University. The authors also thanks Dr. Sema TETIKER, who contributed to K-Ar isotopic analysis.

\section{References}

Çubukçu, H.E., Ulusoy, I., Aydar, E., Ersoy, O., Şen, E., Gourgaud, A., and Guillou, H., 2012. Mt. Nemrut volcano (Eastern Turkey): temporal petrological evolution. J Volcanol Geotherm Res 209-210:33-60.

Eby, G.N., 2011. A-type granites: magma sources and their contribution to the growth of the continental crust. Seventh Hutton Symposium on Granites and Related Rocks, pp. 5051.

Karaoğlu, Ö., Özdemir, Y., Tolluoğlu, A.Ü., Karabıyıkoğlu, M., Köse, O., and Froger, J.-L., 2005.Stratigraphy of the volcanic products around Nemrut Caldera: implications for reconstruction of the caldera formation. Turkish Journal of Earth Sciences 14, 123-143.

Kay, S.M., and Copeland, P., 2006. Early to middle Miocene back-arc magmas of the Neu-quén Basin: geochemical consequences of slab shallowing and the westward drift of South America. Geological Society of America Special Paper $407,185-213$.

Koralay, T., Özkul, M., Kumsar, H., Çelik, S.B., and Pektaş,K., 2011. The effect of welding degree on geotechnical properties of an ignimbrite flow unit: the Bitlis castle case (eastern turkey). Environ. Earth Sci. 64, 869-881.

Koralay, T., Özkul, M., Kumsar, H., Çelik, S.B. ve Pektaş, K., 2014. Tarihi Yapılarda Mineralojik, Petrografik ve Jeoteknik Çalışmaların Önemi: Bitlis Kalesi Örneği (Bitlis-Doğu Anadolu). Selçuk Üniv. Müh.-Mim. Fak. Dergisi, Sayı, 2-3, s.54-68.

Le Maitre, R.W., Streckeisen, A., Zanettin, B., Le Bas, M.J., Bonin, B., Bateman, P.,Bellieni, G., Dudek, A., Efremova, S., Keller, J., Lameyre, J., Sabine, P.A., Schmid,R., Sorensen, H., and Woolley, A.R., 2002. Igneous Rocks: A Classification and Glossary of Terms. Recommendations of the International Union of Geological Sciences Subcommission on the Systematics of Igneous Rocks Cambridge University Press, p. 236.

Medlin, C., Jowitt, S., Cas, R., Smithies, R., Kirkland, C., Maas, R., Raveggi, M., Howard, and H.,Wingate, M., 2015. Petrogenesis of the A-type, Mesoproterozoic intra-caldera rheomorphic Kathleen ignimbrite and comagmatic Rowland suite intrusions, West Musgrave Province, Central Australia: products of extreme fractional crystallizationin a failed rift setting. J. Petrol. 56, 493-525.

Özdemir, Y., Karaoglu, Ö., Tolluoglu, A.U., and Gulec, N., 2006. Volcanostratigraphy and petrogenesis of the Nemrut stratovolcano, East Anatolian High Plateau): the most recent post-collisional volcanism in Turkey. Chemical Geology 226, 189-211.

Pearce, J.A., 1996. Sources and settings of granitic rocks. Episodes 19, 120-125.

Rudnick, R.L., and Gao, S., 2004. Composition of the Continental Crust. In: Rudnick, R.L.(Ed.), Treatise on Geochemistry. 
Elsevier-Pergamon, Oxford, pp. 1-64.

Saunders, A.D., Storey, M., Kent, R.W., and Norry, M.J., 1992. Consequences of plume-lithosphere interactions. In: B.C. Storey, T. Alabaster \& R.J. Pankhurst, Eds., Magmatism and the causes of continental break-up. Geol. Soc. Spec. Publ., $68,41-60$

Schmincke, H-U., Sumita, M., and Paleovan scientific team., 2014. Impact of volcanism on the evolution of Lake Van (eastern Anatolia). III. Periodic (Nemrut) vs. episodic (Süphan) explosive eruptions and climate forcing reflected in a tephra gap between ca. $14 \mathrm{ka}$ and ca. $30 \mathrm{ka}$. J Volcanol Geotherm Res 285:195-213.

Sumita, M., and Schmincke, H-U., 2013. Impact of volcanism on the evolution of Lake Van I: evolution of explosive volcanism of Nemrut Volcano (eastern Anatolia) during the past $>400,000$ years. Bull Volcanol 75:1-32.

Sun, S.S., and Mc Donough, W.F., 1989. Chemical and isotopic systematics of oceanic basalts: implications for mantle composition and processes. In: Saunders, A.D., Norry, M.J. (Eds.), Magmatism in Ocean Basins, Geological Society of London Spec. Publ., vol. 42, pp. 313-345.

Şengün, M., Çağlayan, A., and Sevin, M., 1991. Bitlis Masifi; Bitlis-Tatvan-Hizan-Şirvan dolayının jeolojisi (in Turkish). MTA Report No 9105.

Whalen, J.B., Currie, K.L., and Chappell, B.W., 1987. A-type granites geochemical characteristics, discrimination, and petrogenesis. Contributions to Mineralogy and Petrology95, 407-419. 